\title{
Growth and the Inducibility of Mycelium Formation in Candida albicans: a Single-cell Analysis Using a Perfusion Chamber
}

\author{
By DAVID R. SOLL* AND MICHAEL A. HERMAN \\ Department of Zoology, University of Iowa, Iowa City, Iowa 52242, U.S.A.
}

(Received 23 November 1982; revised 19 April 1983)

\begin{abstract}
In Candida albicans, cells actively growing in the budding form cannot be immediately induced to form a mycelium until they enter stationary phase. However, if exponential phase cells are starved for a minimum of 10 to $20 \mathrm{~min}$, they are inducible. Using a video-monitored perfusion chamber, we found that starved cells were able to form mycelia regardless of their position in the budding cycle. When starved exponential cells were released into fresh nutrient medium at high temperature and $\mathrm{pH}$, conditions conducive to mycelium formation, unbudded cells evaginated after an average lag period of $75 \mathrm{~min}$ and then grew exclusively in the mycelial form. Depending upon the volume, or maturity, of the bud, budded cells entered two different avenues of outgrowth leading to mycelium formation. If the daughter bud was small, growth resumed by apical elongation of the bud, leading to a 'shmoo' shape which tapered into an apical mycelium. If the daughter bud was large, the cell underwent a sequence of evaginations: first, the mother cell evaginated after an average period of $75 \mathrm{~min}$; then the daughter bud evaginated $40 \mathrm{~min}$ later. Both evaginations then grew in the mycelial form. In this latter sequence, the evagination on the mother cell was positioned non-randomly, occurring in the majority of cells adjacent to the bud. All buds undergoing evagination contained a nucleus, but roughly $20 \%$ of buds undergoing apical elongation did not.
\end{abstract}

\section{INTRODUCTION}

Candida albicans is capable of growing either in a budding yeast form or a tubular mycelial form. Although several studies have indicated that transition from the budding to mycelial form can be induced only after budding cells have entered stationary phase (Chaffin \& Sogin, 1976; Soll \& Bedell, 1978), evidence was recently presented that under at least one set of conditions, exponential phase cells could also be induced to form mycelia (Mattia \& Cassone, 1979). These conflicting results may be reconcilable if a transient cessation of growth is all that is required for the acquisition of pluripotency in Candida albicans. In this study, this possibility has been tested and found to be the case. In addition, it is demonstrated that the mode of mycelial outgrowth differs depending upon the size, or maturity, of the daughter bud after starvation.

\section{METHODS}

Growth and maintenance of cultures. The methods used to maintain stock cultures of Candida albicans, strain 3153A, were identical to those previously reported (Soll \& Bedell, 1978; Soll et al., 1978; Bedell et al., 1980). For experimental purposes, cells from an agar culture were first cloned, and then inoculated in $25 \mathrm{ml}$ defined medium (Lee et al., 1975) supplemented with $70 \mu \mathrm{g}$ arginine $\mathrm{ml}^{-1}$ in a $125 \mathrm{ml}$ plastic Erlenmeyer flask and mixed at 200 r.p.m. at $25^{\circ} \mathrm{C}$ in a rotatory shaker (New Brunswick). Cells were serially grown to stationary phase twice, then tested for normal generation time (Soll \& Bedell, 1978), normal final stationary phase concentration (Soll et al., $1981 \mathrm{a}$ ), and normal outgrowth kinetics in the budding form at low pH (Mitchell \& Soll, $1979 a$; Bedell et al., 1980 ; Soll et al., 1981 b) and in the mycelial form at high pH (Soll et al., 1978; Mitchell \& Soll, 1979a; Soll et al., 1981 b) before being used in an experiment.

Starvation conditions. Cells were grown to mid-exponential phase $\left(\sim 2 \times 10^{7}\right.$ spheres $\left.\mathrm{ml}^{-1}\right)$ at $25^{\circ} \mathrm{C}$ in defined medium, then diluted 100 -fold in fresh medium. This was done in sequence three times to ensure that the 


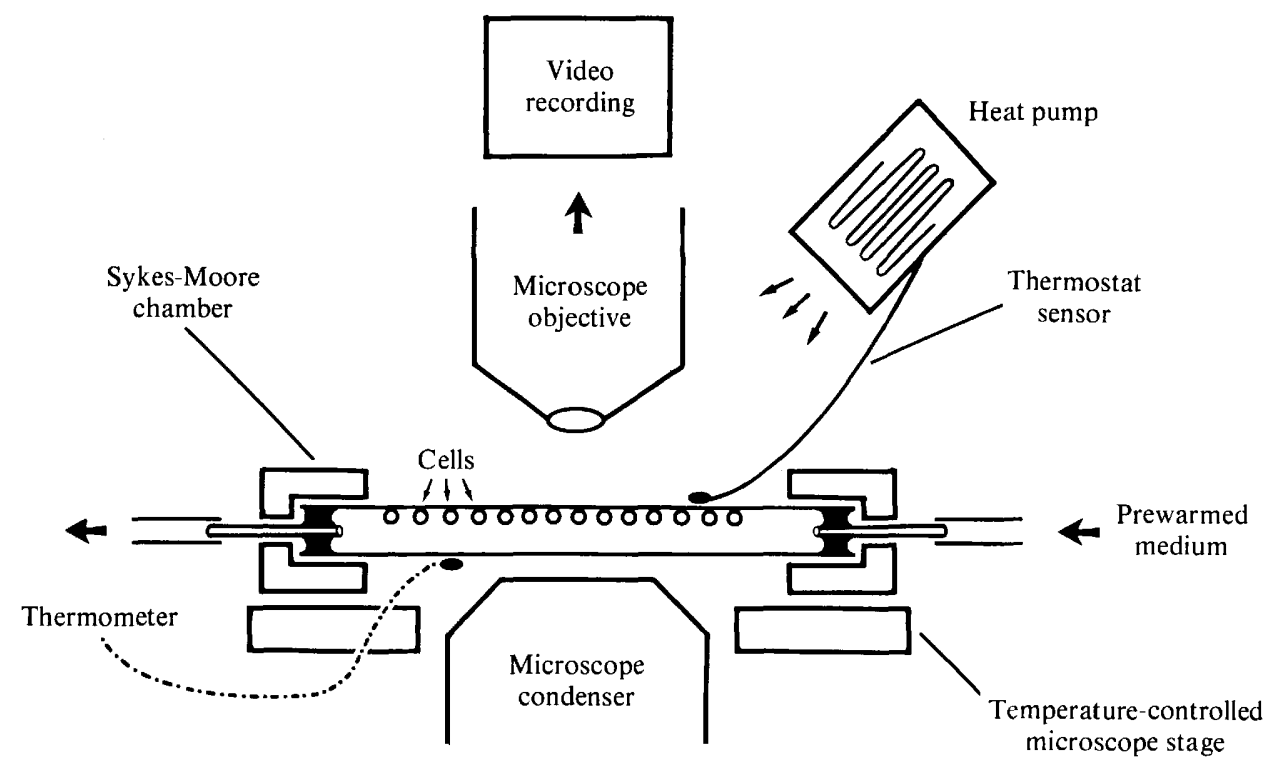

Fig. 1. Diagram of the video-monitored perfusion chamber. Cells adhere to one side of the chamber, which has been treated with polylysine. Details of the chamber are given in Methods.

exponential phase cell population had equilibrated. Cells were then pelleted, washed with a non-nutrient buffered salts solution [ $5 \mathrm{~g} \mathrm{NaCl}, 5 \mathrm{~g}\left(\mathrm{NH}_{4}\right)_{2} \mathrm{SO}_{4}, 2.5 \mathrm{~g} \mathrm{~K}_{2} \mathrm{HPO}_{4}$ (anhydrous), $0.2 \mathrm{~g} \mathrm{MgSO}_{4} .7 \mathrm{H}_{2} \mathrm{O}$, in 1 litre of double-

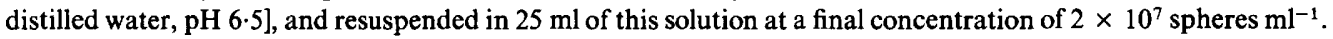
Cells were then mixed at 200 r.p.m. at $25^{\circ} \mathrm{C}$ on a rotatory shaker. The starvation medium contained the inorganic ingredients of the standard defined nutrient medium (Lee et al., 1975).

Induction of mycelium formation. The method for inducing synchronous mycelium formation has been reported elsewhere (Bedell \& Soll, 1979; Mitchell \& Soll, 1979 $a$; Soll et al., 1981 b; Brummel \& Soll, 1982). Briefly, cells were grown to stationary phase at $25^{\circ} \mathrm{C}$, then diluted into fresh medium at $37^{\circ} \mathrm{C}$. If the release medium was at $\mathrm{pH} 4.5$, cells synchronously formed buds; if at $\mathrm{pH} 6.5$, cells synchronously formed mycelia. To test for the capacity of mycelium formation in exponential phase cultures or starved cultures, cells were simply diluted into fresh medium at $37^{\circ} \mathrm{C}$, pH 6.5. At subsequent intervals, cells were removed and scored under phase optics for the percentage of cells with mycelia.

Video analysis of single cells in a perfusion chamber. The perfusion chamber and accessory equipment are shown diagrammatically in Fig. 1. A droplet of cell suspension was placed on one side of the chamber wall of a SykesMoore chamber (Bellco Glass Inc., N.J., U.S.A.) previously coated with polylysine. The opposing chamber wall was immediately set in place and the chamber perfused with prewarmed nutrient medium. The temperature of the chamber was controlled by an air current incubator (Sage model 299 , Orion Research Inc., Ma., U.S.A.), a thermal microscope stage (model TS-2, Bailey Instruments Inc., N.J., U.S.A.), and prewarmed medium (Fig. 1). Temperature was maintained at $37^{\circ} \mathrm{C}\left( \pm 0.5^{\circ} \mathrm{C}\right)$ and monitored either by a digital thermometer (model 5650, Markson Scientific, Az., U.S.A.) with a surface probe attached to the metal rim of the chamber, or by a digital thermometer (model BAT-12, Bailey Instruments) inserted into the chamber interior. Medium was perfused through the chamber by a peristaltic pump (model 2120 , LKB Instruments Inc., Md., U.S.A.) attached to the outflow tube. Medium was pumped at a rate of $0.5 \mathrm{ml} \mathrm{min}^{-1}$, which resulted in turnover of the chamber medium once per minute.

The chamber was mounted on a trinocular Leitz compound microscope equipped with a video camera attached to the vertical ocular. Cultures were continuously viewed through a Panasonic Electrotune video monitor, and a recording of the culture made with a Panasonic video cassette recorder.

Volume measurements of cells. Cells were placed on a standard glass slide, overlaid with a coverslip, and viewed under phase optics $(1000 \times$ magnification) through a video monitor [19 in $(48 \mathrm{~cm})$ diagonal screen size]. Each unbudded cell, mother cell, and daughter bud was measured on the video screen for the major axis (length) and minor axis (width). Volumes were calculated by using the equation for an ellipsoid.

Nuclear staining. Nuclei were stained with acridine orange according to methods previously described (Soll et al., 1978). 


\section{RESULTS}

\section{Mycelium induction in growth cultures}

At $25^{\circ} \mathrm{C}$, Candida albicans grew exclusively in the budding yeast form (Lee et al., 1975; Chaffin \& Sogin, 1976; Soll \& Bedell, 1978). Cells in the mid-exponential phase of growth $\left(25^{\circ} \mathrm{C}\right)$ diluted directly into fresh medium at $37^{\circ} \mathrm{C}$, pH 6.5 (conditions conducive to inducing mycelium formation: Soll \& Bedell, 1978; Soll et al., 1978; Soll et al., 1981 b), formed ellipsoidal buds, but then continued to multiply in the budding form. Virtually no mycelia (scored as elongated daughter cells with diameters roughly one-third the diameter of the mother cell, lengths equal to or greater than one-half the diameter of the mother cell, and no clear constriction at the mother cell-daughter cell junction) were observed even after 300 min at high temperature and high $\mathrm{pH}$. However, after cultures entered stationary phase at $25^{\circ} \mathrm{C}$, dilution of cells into fresh medium at $37^{\circ} \mathrm{C}, \mathrm{pH} 6.5$, resulted in synchronous mycelium formation in over $90 \%$ of the population. These cells continued to grow as mycelia as long as the $\mathrm{pH}$ remained above $\mathrm{pH} 6.5$.

\section{Starvation and the budding cycle}

To test whether starvation of exponential phase cells would lead to mycelium inducibility, we first tested whether cells continued through the cell cycle in the absence of growth when starved. Cells were grown to mid-exponential phase at $25^{\circ} \mathrm{C}$, then diluted into fresh medium at $25^{\circ} \mathrm{C}$ and again grown to mid-exponential phase. This was repeated three times to ensure that the cells had equilibrated in the mid-exponential phase of growth. Cells from the final mid-exponential phase cultures were then rapidly washed free of nutrient medium and resuspended in a rotating flask containing non-nutrient, buffered salts solution. Samples were removed from the starvation flask at intervals and sonicated, and the percentage of unbudded and budded cells was monitored. Results of a representative experiment are presented in Fig. 2. Approximately $20 \%$ of the cells in the initial mid-exponential phase culture were unbudded. With increasing time of starvation, the percentage of unbudded cells continued to increase and the percentage of budded cells decreased. After roughly $150 \mathrm{~min}$ starvation, the percentage of unbudded cells had increased to roughly $75 \%$. These percentages remained relatively stable for at least the next 100 min (Fig. 2a). The concentration of spheres also remained relatively stable (see Fig. $2 c$ ). When budded cells were further subdivided into those with very small buds (volumes less than $20 \%$ of mother cell volume) and those with large buds (volumes greater than $20 \%$ of mother cell volume), it was obvious that the proportion of cells with small buds dropped from approximately $17 \%$ to $10 \%$, whereas the proportion of cells with large buds dropped from approximately $60 \%$ to $13 \%$ (Fig. $2 b$ ). Therefore, with time the majority of cells with maturing buds cycled into the unbudded cell population. Together, the above results demonstrate that with increasing time of starvation, cells progress through the budding cycle and become separable by light sonication, indicating that cytokinesis and perhaps cell separation are complete.

To test whether nuclear division occurred under starvation conditions in budded cells, we examined the nuclear content of unbudded and budded cells during starvation (Table 1). Approximately $70 \%$ of maturing buds contained nuclei throughout the starvation period, but $100 \%$ of the unbudded cell population contained nuclei (Table 1). Since the majority of the unbudded cell population by $185 \mathrm{~min}$ of starvation originated from the budding population (Fig. $2 a$ ), two alternatives could account for the fact that all unbudded cells contained nuclei. Either all new unbudded cells were derived from cells with buds containing nuclei at the onset of starvation, or new unbudded cells were derived from both cells with buds initially containing nuclei and cells with buds which acquired nuclei during the starvation period. If no nuclear division occurred during starvation, then all new unbudded cells would have to be derived from budded cells containing nucleated buds prior to starvation, and the proportion of budded cells with nucleated buds would then decrease dramatically by $185 \mathrm{~min}$. Since this proportion remained relatively constant, it is likely that nuclear division did occur in the starving population, but a direct test of this alternative must be performed. 

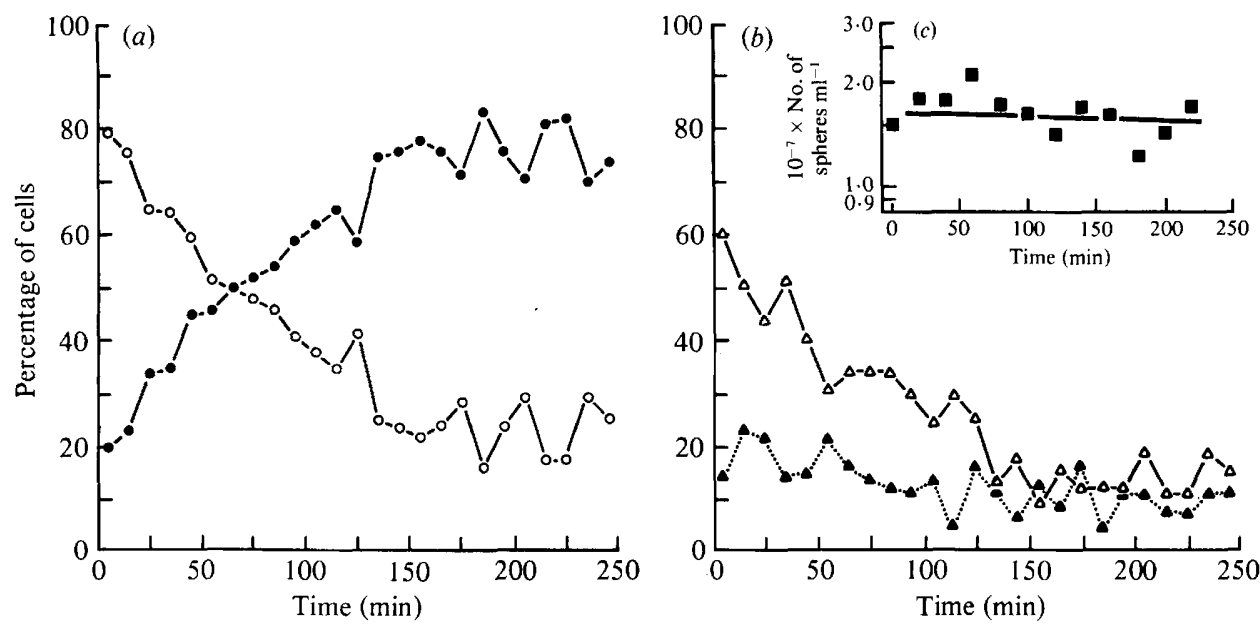

Fig. 2. Proportion of unbudded cells and budded cells during prolonged starvation of an exponential phase culture. A mid-exponential phase culture $\left(25^{\circ} \mathrm{C}\right)$ was washed free of nutrient medium and resuspended in a buffered salts solution (standard growth medium lacking all organic components, $\left.25^{\circ} \mathrm{C}, \mathrm{pH} 6 \cdot 5\right)$. At various times thereafter, samples were removed, lightly sonicated, and scored for $(a)$ the proportion of unbudded cells $(\mathcal{O})$ and budded cells (including cells with small evaginations as well as maturing and mature buds) $(O),(b)$ the proportion of budded cells with a bud volume less than $20 \%$ of the volume of the mother cell $(\Delta)$, or greater than $20 \%$ of the volume of the mother cell $(\triangle)$, and $(c)$ the concentration of spheres per $\mathrm{ml}$.

Table 1. Nuclear content during prolonged starvation of exponential phase cells

Nuclei were stained with acridine orange (see Methods). All cells encountered during a random scan of a preparation were scored.

\begin{tabular}{|c|c|c|c|c|c|}
\hline $\begin{array}{l}\text { Starvation } \\
\text { time (min) }\end{array}$ & 5 & 65 & 125 & 185 & 245 \\
\hline \multicolumn{6}{|l|}{ Unbudded cells } \\
\hline No. scored & 20 & 40 & 57 & 72 & 77 \\
\hline$\%$ with nucleus & 100 & 100 & 100 & 100 & 100 \\
\hline \multicolumn{6}{|l|}{ Budded cells } \\
\hline \multicolumn{6}{|l|}{ Mother cells } \\
\hline No. scored & 80 & 60 & 43 & 28 & 23 \\
\hline$\%$ with nucleus & 100 & 100 & 100 & 100 & 100 \\
\hline \multicolumn{6}{|l|}{ Buds } \\
\hline No. scored & 80 & 60 & 43 & 28 & 23 \\
\hline$\%$ with nucleus & 45 & 48 & 53 & 46 & 60 \\
\hline
\end{tabular}

Since cells are progressing through the budding cycle in the absence of nutrients, they are probably doing so in the absence of growth. We therefore measured the widths and lengths of mother cells and buds, and of unbudded cells during starvation. Cell volumes were then computed by using the formula for an ellipsoid. The results are presented in Table 2 . The average volume of unbudded cells decreased from approximately $76 \mu \mathrm{m}^{3}$ to $48 \mu \mathrm{m}^{3}$ between zero and $240 \mathrm{~min}$ of starvation, a decrease of $37 \%$. The average volume of buds decreased from $24 \mu \mathrm{m}^{3}$ to $7 \mu \mathrm{m}^{3}$ between zero and $240 \mathrm{~min}$, a decrease of $71 \%$. In addition, the ratio of bud to mother cell volume decreased from 0.27 to $0 \cdot 12$, indicating that cells with larger buds were preferentially cycling into the unbudded cell population. 
Table 2. Effects of starvation on cell volume

Mid-exponential phase cultures were washed free of nutrient medium, suspended in a buffered salts solution, and rotated. At intervals, samples were removed, briefly sonicated, and projected on to a video screen for measurement (see Methods). All cells encountered during a random scan of the preparation were measured. $N$, number of cells measured; $l$, length; $w$, width; $V$, volume (calculated by using the formula for an ellipsoid). The ' \pm ' terms are standard deviations.

\section{Starvation}

time $(\mathrm{min}) \ldots 0$

Unbudded cells

Expt 1.

Expt 2. $N$

$l(\mu \mathrm{m})$ $w(\mu \mathrm{m})$

$l(\mu \mathrm{m})$

$w(\mu \mathrm{m})$

Ave, $l(\mu \mathrm{m})$

Ave. $w(\mu \mathrm{m})$

Ave. $V\left(\mu \mathrm{m}^{3}\right) \quad 76$

Budded cells

Mother cells

Expt 1. $N$

\section{$l(\mu \mathrm{m})$}

Expt 2. $N$

$w(\mu \mathrm{m})$

$l(\mu \mathrm{m})$

$w(\mu \mathrm{m})$

Ave. $l(\mu \mathrm{m})$

Ave. $w(\mu \mathrm{m})$

Ave. $V\left(\mu \mathrm{m}^{3}\right)$

73
$5.9 \pm 0 \cdot 6$
$5 \cdot 0 \pm 0 \cdot 7$
78
$6 \cdot 1 \pm 0 \cdot 6$
$5 \cdot 6 \pm 0 \cdot 6$
$6 \cdot 0$
$5 \cdot 3$
88

Buds

Expt 1. $N$

$$
l(\mu \mathrm{m})
$$$$
w(\mu \mathrm{m})
$$

Expt 2. $N$

$$
\begin{aligned}
& l(\mu \mathrm{m}) \\
& w(\mu \mathrm{m})
\end{aligned}
$$

Ave. $l(\mu \mathrm{m})$

Ave. $w(\mu \mathrm{m})$

Ave. $V\left(\mu \mathrm{m}^{3}\right)$

Ratio of bud to

mother cell volume
60

35

$5 \cdot 5+1 \cdot 1$

$4 \cdot 8 \pm 0 \cdot 6$

36

$5 \cdot 8 \pm 0 \cdot 9$

$5.2 \pm 0.8$

5.65

$5 \cdot 0$

74
120

43

$5 \cdot 2 \pm 0 \cdot 8$

$4.4 \pm 0.7$

49

$5 \cdot 8 \pm 0 \cdot 7$

$4.8 \pm 1 \cdot 1$

$5 \cdot 5$

$4 \cdot 6$

61
180

66

$5 \cdot 4 \pm 0 \cdot 8$

$4.6 \pm 0.7$

62

$5.3 \pm 0.9$

$4.6 \pm 0.7$

$5 \cdot 35$

$4 \cdot 6$

59
240

67

$5.0 \pm 0.8$

$4.2 \pm 0.7$

66

$5 \cdot 2 \pm 0 \cdot 7$

$4 \cdot 3 \pm 0.7$

$5 \cdot 1$

$4 \cdot 25$

48

$\begin{array}{lcc}58 & 34 & 33 \\ 5.4 \pm 0.5 & 5.5 \pm 0.4 & 5 \cdot 2 \pm 0.5 \\ 4.7 \pm 0.5 & 4.8 \pm 0.4 & 4.4 \pm 0.5 \\ 50 & 37 & 34 \\ 5.9 \pm 0.7 & 5.5 \pm 0.6 & 5.4 \pm 0.6 \\ 5.2 \pm 0.8 & 4.8 \pm 0.5 & 4.7 \pm 0.5 \\ 5.65 & 5.5 & 5.3 \\ 4.95 & 4.8 & 4.55 \\ 72 & 66 & 57\end{array}$

\section{5}

$3 \cdot 2 \pm 1 \cdot 2$

$2 \cdot 8 \pm 1 \cdot 1$

65

$3 \cdot 6 \pm 1 \cdot 2$

$3 \cdot 3 \pm 1 \cdot 1$

3.4

3.05

$16 \cdot 6$

58

$3 \cdot 0 \pm 1 \cdot 3$

34

$2.7 \pm 1 \cdot 1$

50

$2.9 \pm 1 \cdot 5$

$2.7 \pm 1.4$

$2 \cdot 95$

$2 \cdot 7$

$11 \cdot 3$

$2 \cdot 8 \pm 1 \cdot 2$

33

$\begin{array}{ll}2.6 \pm 1.1 & 2.8 \pm 1.1\end{array}$

37

$2 \cdot 9 \pm 1 \cdot 1 \quad 2.2 \pm 1.0$

$3.05 \quad 2.55$

$2 \cdot 75 \quad 2 \cdot 3$

$12 \cdot 1 \quad 7 \cdot 1$

$\begin{array}{ll}0 \cdot 16 & 0 \cdot 18\end{array}$

$0 \cdot 12$

\section{Mycelium induction and starvation}

To test whether starvation of exponential phase cells results in their capacity to form mycelia when induced, cells from mid-exponential phase cultures at $25^{\circ} \mathrm{C}$ were washed free of nutrient medium and resuspended in fresh medium at $37^{\circ} \mathrm{C}, \mathrm{pH} 6.5$. Mycelium formation was then followed in these latter cultures (Fig. 3). Cells starved for 0,5 and 10 min periods evaginated and formed elongate daughter buds which were initially mistaken for young mycelia (Fig. 3). However, these daughter cells soon reverted to the more ellipsoidal shape of budding cells, a phenotype referred to as the 'revertant' phenotype (Buffo et al., 1983), and then continued to multiply exclusively in the budding form. Therefore, the percentage of cells scored with germ tubes, or young mycelia, in released cultures which had been starved for 0,5 and 10 min initially increased to approximately $40 \%$ by $70 \mathrm{~min}$ and to $55 \%$ by $120 \mathrm{~min}$, but then decreased to below $15 \%$ by $180 \mathrm{~min}$ (Fig. 3 ). 


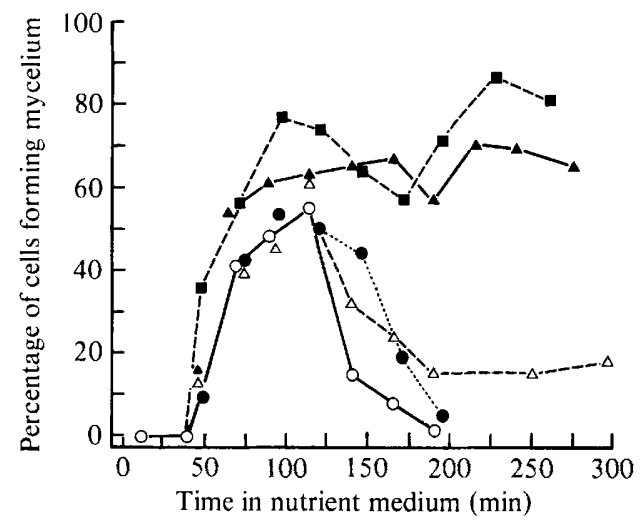

Fig. 3. Mycelium induction in exponential phase cells starved for various periods. Exponential phase cells growing at $25^{\circ} \mathrm{C}$ were washed free of nutrients and resuspended in non-nutrient salts solution. At 0 $(\bigcirc), 5(\bigcirc), 10(\triangle), 20(\Delta)$, and $40(\square) \mathrm{min}$, cells were removed and diluted into fresh nutrient medium at high temperature $\left(37^{\circ} \mathrm{C}\right)$ and high $\mathrm{pH}(6 \cdot 5)$, conditions conducive to mycelium formation. Mycelia in this case were scored as elongate daughter compartments with lengths equal to or greater than half of the diameter of the mother cell and diameters no greater than one-third of the diameter of the mother cell. Because daughter buds were initially tubular for cells starved for 0,5 , and $10 \mathrm{~min}$, they were initially misidentified as mycelia. However, these daughter cells then reverted to ellipsoidal cells. These cells then grew exclusively in the budding form. In contrast, cells starved for 20 and 40 min continued to grow as true mycelia.

When cells starved for 20 and 40 min were released into fresh nutrient medium at $37^{\circ} \mathrm{C}$, they also formed initial ellipsoidal daughter cells at approximately the same rate as cells starved for shorter periods. However, these daughter compartments did not revert to the budding form; rather, they continued to grow in the mycelial form even after $240 \mathrm{~min}$, at which time between 70 and $80 \%$ of the population possessed true mycelia (Fig. 3). These results demonstrate that a minimum starvation period is required before exponential phase cells can be induced to grow in the mycelial form.

It should be noted that in the above experiments with starved cells the $\mathrm{pH}$ of the nutrient medium fell quite rapidly. As we have reported elsewhere (Buffo et al., 1983), if the $\mathrm{pH}$ of the culture medium falls below $\mathrm{pH} 6.0$, cells will rapidly revert to the budding growth form regardless of the period of starvation. To avoid this decrease, the $\mathrm{pH}$ of the medium was adjusted to 6.7 every $30 \mathrm{~min}$ by the addition of microdroplets of $0.1 \mathrm{M}-\mathrm{NaOH}$ solution so that the $\mathrm{pH}$ of the medium never fell below $\mathrm{pH} 6 \cdot 4$.

\section{Video analysis of mycelium formation by single cells}

The majority of cells in a culture starved for $20 \mathrm{~min}$ had acquired the capacity to form mycelia (Fig. 3). However, as is evident in Fig. 2(a), the proportion of budded cells in this population had not changed significantly from a mid-exponential phase culture, indicating that cells were still heterogeneously dispersed throughout the cell cycle. In the mass-culture experiments described in the previous section, it was impossible to assess the relationship between mycelium formation and the budding cycle, or the temporal sequence of evagination and mycelium formation by a mother cell and its attached bud. To do this, it is necessary to study individual cells which have been starved and then released into medium conducive to mycelium formation. For this purpose, we used a perfusion chamber mounted on a microscope stage with a variety of temperature controls (see Fig. 1 and Methods).

To ensure that the chamber supported normal bud or mycelium formation, stationary phase cells were released into the chamber and perfused with fresh nutrient medium at $37^{\circ} \mathrm{C}$, at either pH 4.5 to induce synchronous bud formation (Fig. 4) or pH 6.5 to induce synchronous mycelium formation (Fig. 5). The former population evaginated after an average lag period of $150 \mathrm{~min}$ and 
continued to grow exclusively in the budding form (Fig. 4). The latter population evaginated after an average lag period of $150 \mathrm{~min}$ and continued to grow exclusively in the mycelial form (Fig. 5). Although less synchronous than mass-culture outgrowth, the single cell kinetics were similar enough to those obtained in mass cultures (e.g. see Soll et al., 1981 b) to indicate that the perfusion chamber environment, including the lack of conditioning of the medium and the adhesion of cells to the polylysine-coated chamber wall, did not interfere significantly with the normal establishment of alternative phenotypes and subsequent growth.

Since the chamber environment did not interfere with normal mycelium induction, exponential phase cells were starved for $20 \mathrm{~min}$, sufficient for them to acquire the capacity to form a mycelium (Fig. 3), and then released into a chamber and perfused with fresh nutrient medium at $37^{\circ} \mathrm{C}, \mathrm{pH} 6.5$. Unbudded cells, which composed approximately $20 \%$ of the starved population, evaginated after an average period of $75 \mathrm{~min}$ (Fig. 6, Fig. $7 \mathrm{a}$ ). Evaginations which formed on unbudded cells then continued to grow in a true mycelial form (Fig. 6). In a very few cases, unbudded cells evaginated quite early (at roughly $30 \mathrm{~min}$ ), and the daughter cells then grew into ellipsoidal buds which in turn evaginated later and gave rise to mycelia. It is likely that these few cells were at a point late in the pre-evagination period and were already committed to the budding phenotype for the next, but not subsequent, daughter cell compartment (see Mitchell \& Soll, 1979a, $b$; Soll, 1983, for discussions of commitment in C. albicans).

Budded cells showed two relatively distinct patterns of mycelium formation (Fig. 6). Either the bud began to elongate apically, forming a transient 'shmoo' shape which then tapered into an apical mycelium as growth continued (follow a cell labelled 's' in Fig. 6), or the budded cell progressed through a programme of evagination in which first the mother cell and then the daughter bud evaginated (follow 'e's on a budded cell in Fig. 6). In this latter case, the mother cells evaginated with roughly the same kinetics as unbudded cells in the population, and the average daughter bud in turn evaginated roughly $40 \mathrm{~min}$ later (Fig. $7 \mathrm{~b}$ ). Whether a budding cell went through the apical elongation or evagination mode of mycelium formation appeared to depend upon the maturity, or volume, of the bud. This was examined by comparing the distributions of the ratios of daughter bud to mother cell diameters for cells undergoing the two forms of mycelium formation (Fig. 8). Measurements were made on individual cells in perfusion chambers at time zero of release from starvation; then the mode of mycelium formation was assessed by following each budded cell with time. It is clear from the results presented in Fig. 8 that the distributions were dramatically different. Cells with apically elongating buds had a mean ratio of bud to mother cell diameter of 0.51 (for 32 individually measured cells); cells undergoing the sequence of evaginations had a mean ratio of 0.82 (for 48 individually measured cells). When volumes were calculated, the ratio of average daughter bud to mother cell volumes was 0.13 for apically elongating buds and 0.55 for evaginating cells. The distribution of diameter ratios for cells with apically elongating buds was evenly distributed between diameter ratios of 0.4 and 0.8 , which must include those buds early in bud maturation, or growth (Fig. 8). On the other hand, the distribution of diameter ratios for evaginating cells was concentrated at the higher end of the scale, indicating that this population includes the majority of mature buds (Fig. 8).

\section{Position of daughter mycelia}

As noted above, when starved cells with small buds were released into nutrient medium at $37^{\circ} \mathrm{C}$, pH 6.5, they underwent apical bud elongation. These cells usually did not form evaginations on the mother cell (although in Fig. 6 an unusual example of mother cell evagination is evident in the centre of the field). When starved cells with large buds were released, the first evagination was formed on the mother cell. The position of this evagination was not random. To demonstrate this point, the positions of new evaginations on mother cells were scored according to the cell quadrants on which they were positioned (see inset in Fig. 9). The results are presented in Fig. 9 for 100 individually scored cells. Roughly $60 \%$ of mother cell evaginations formed in quadrant 1 (adjacent to the original daughter cell), $25 \%$ in quandrant 2 , $15 \%$ in quadrant 3 , and $0 \%$ in quadrant 4 . Therefore, the majority of first evaginations formed at a position adjacent to the original bud. 


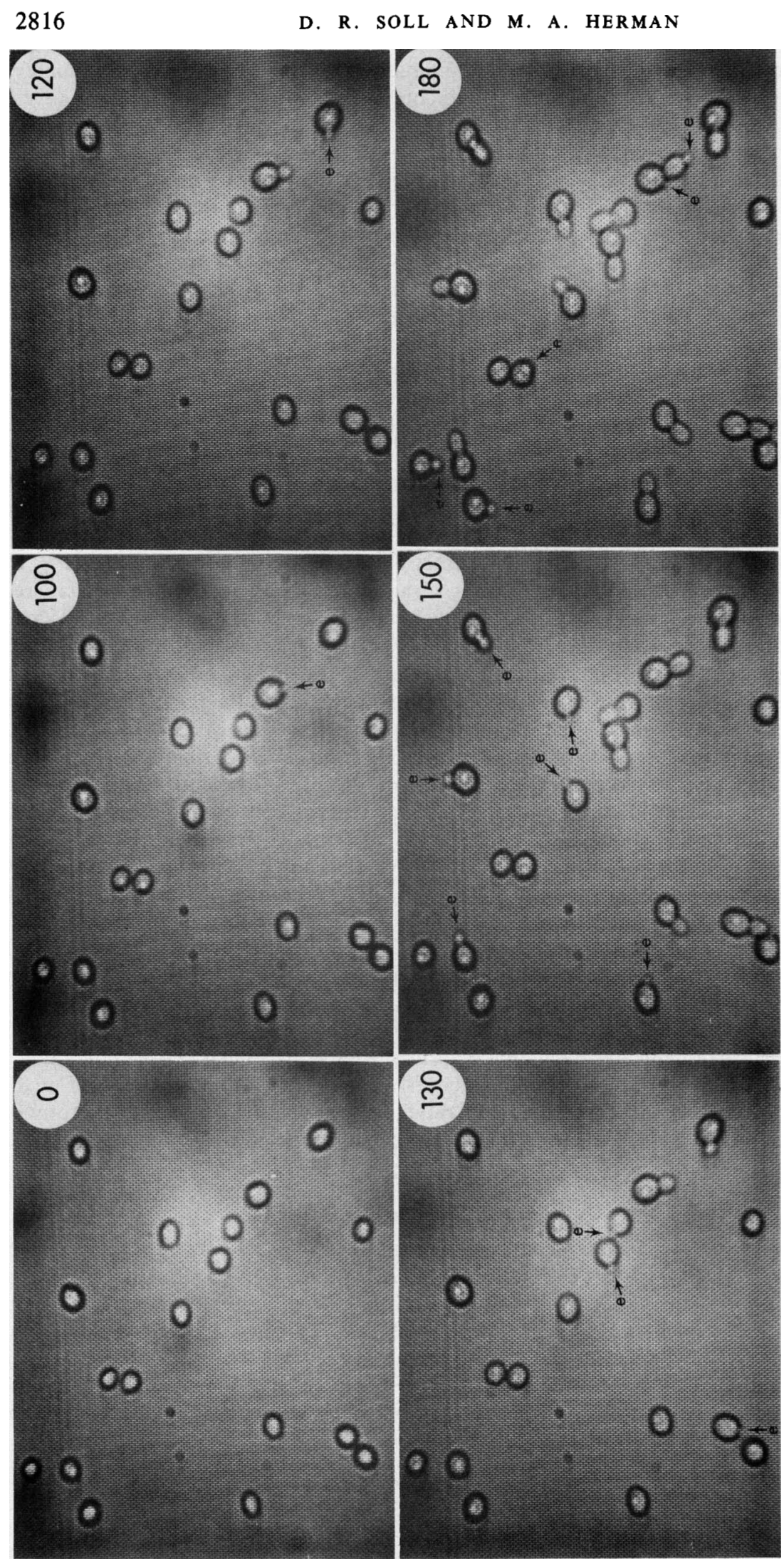



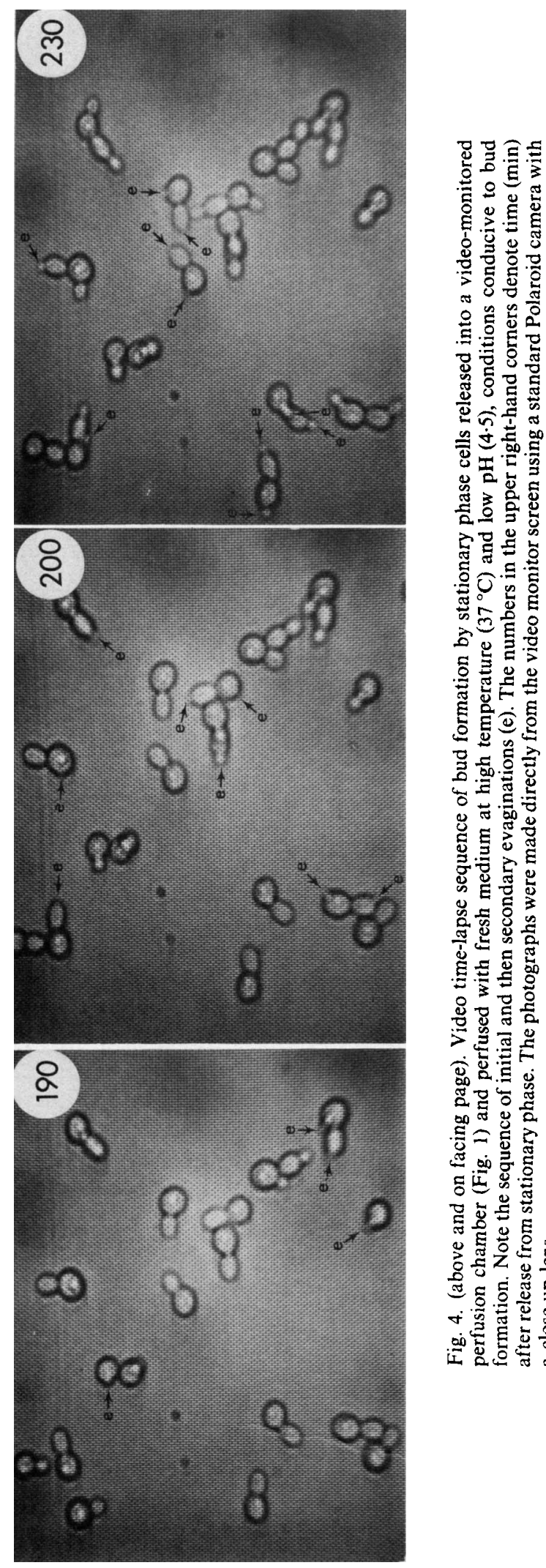

它矛导 ธิ

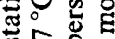
के so 을 氖导 政 这运 둥

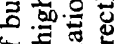
ㄴ. E 每 可证 政

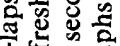
है

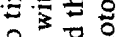
\& $>$ 西

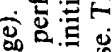
急政 $\infty$ 纤

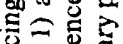
oi 远远要 可吉 है

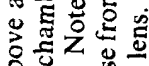
政 + o 


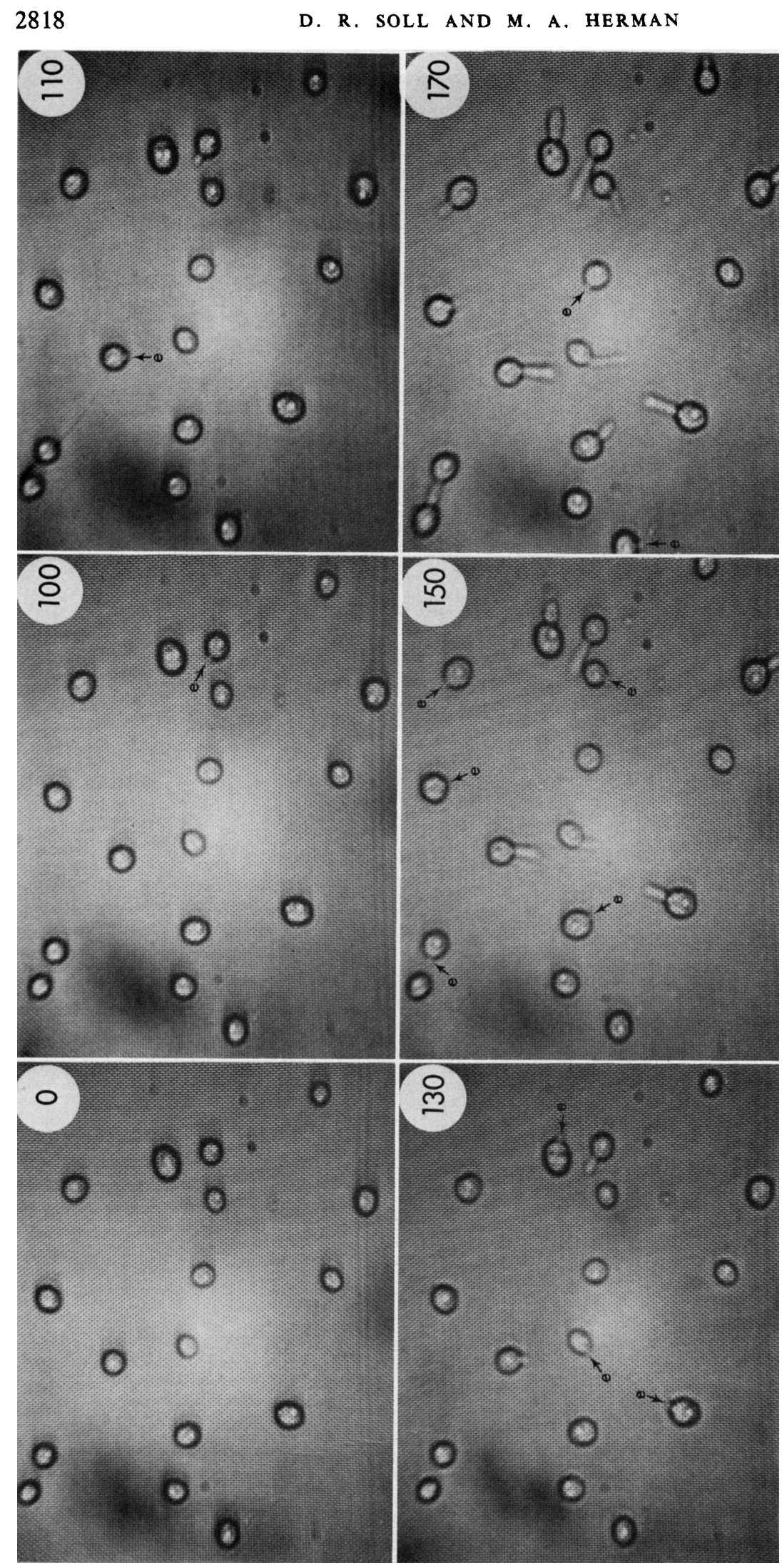



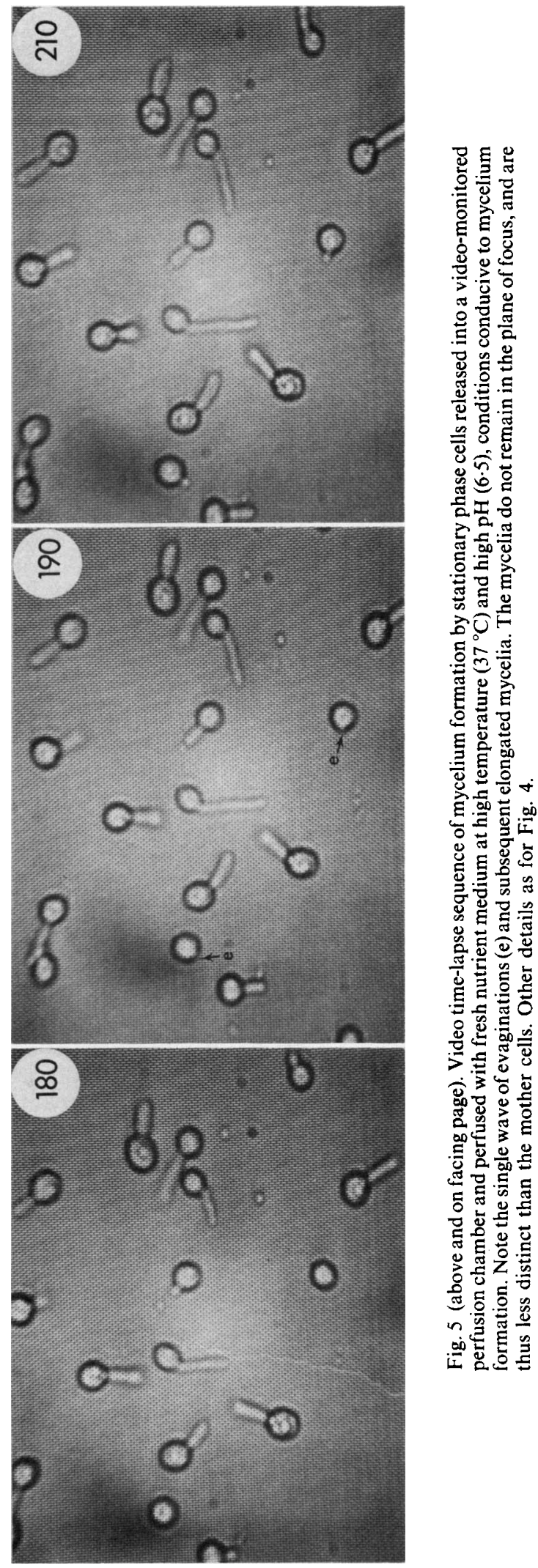
D. R. SOLL AND M. A. HERMAN

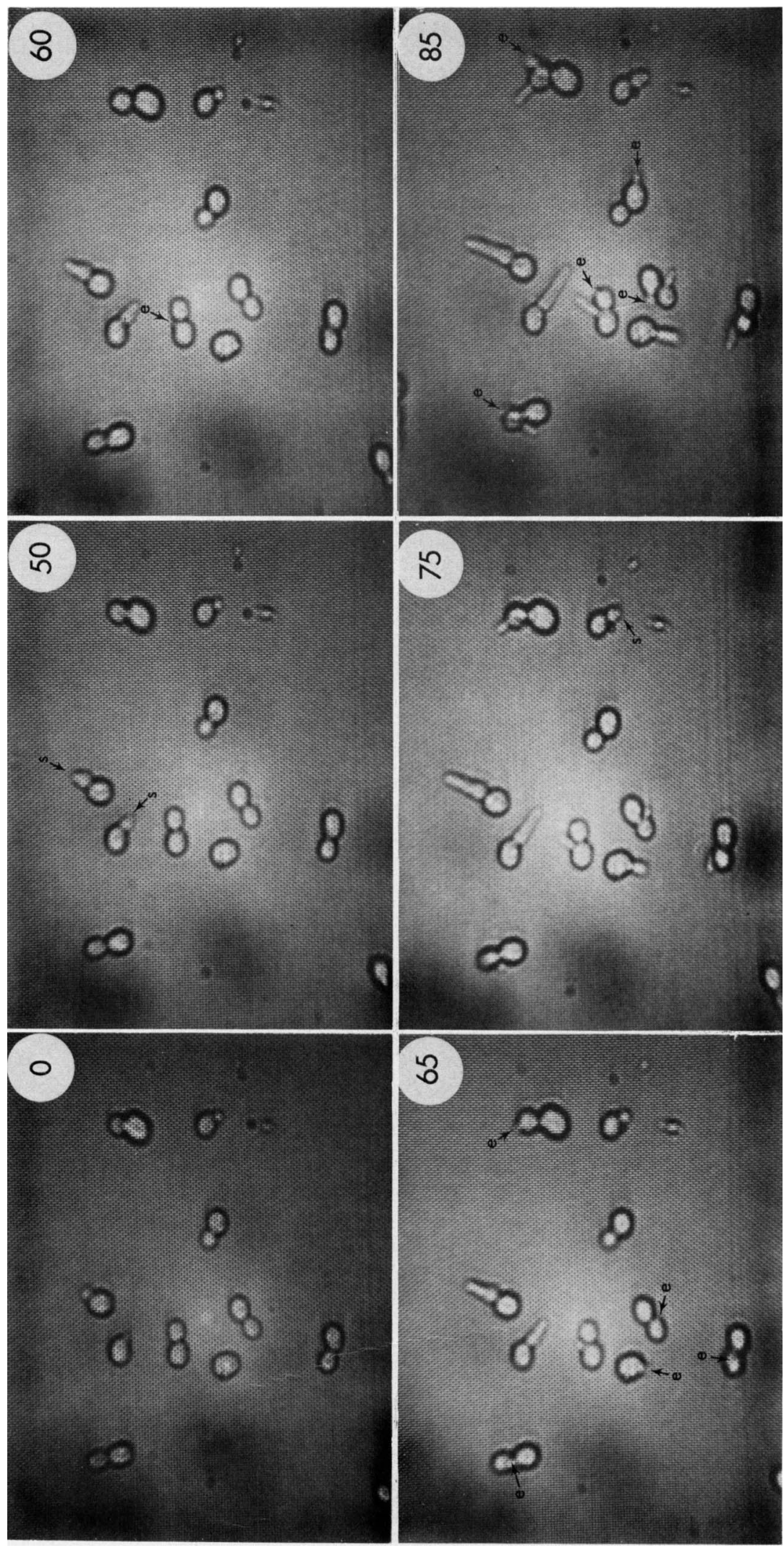



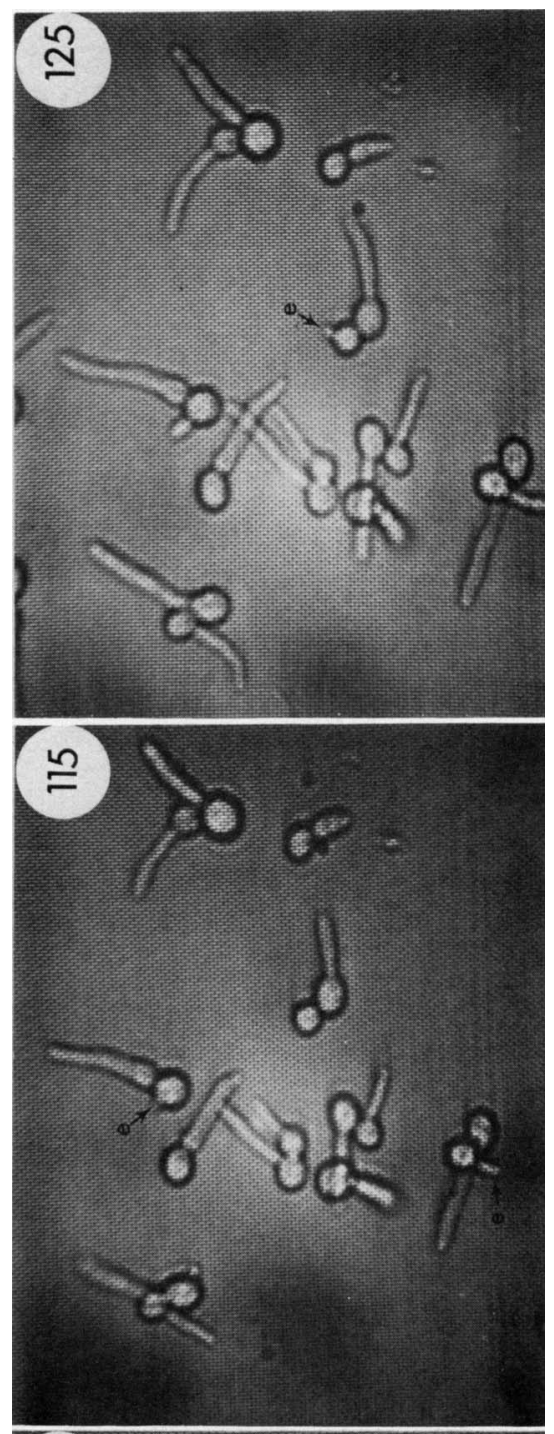

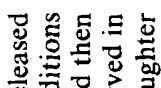
믄릉

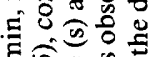

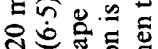

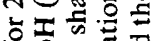
8 .

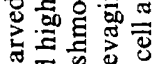

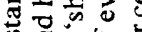
क ส すे。 छ

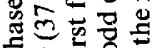
문

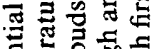

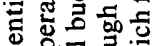

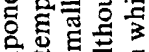
政

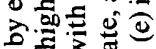

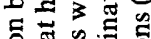
둥 西过 웡

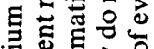

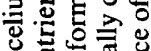

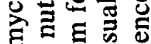
굴 要递 和西

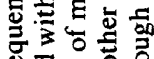
可 品 ह

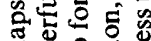
政 踏范 品

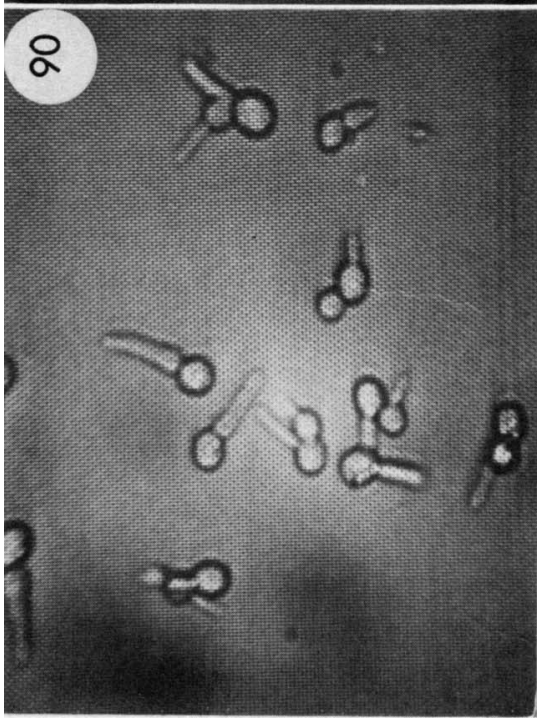
응 蛋 $\mathrm{Z}$ 吃

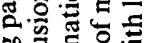
일 造造 형 웡 드워 政

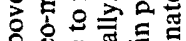
过

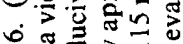

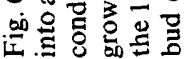



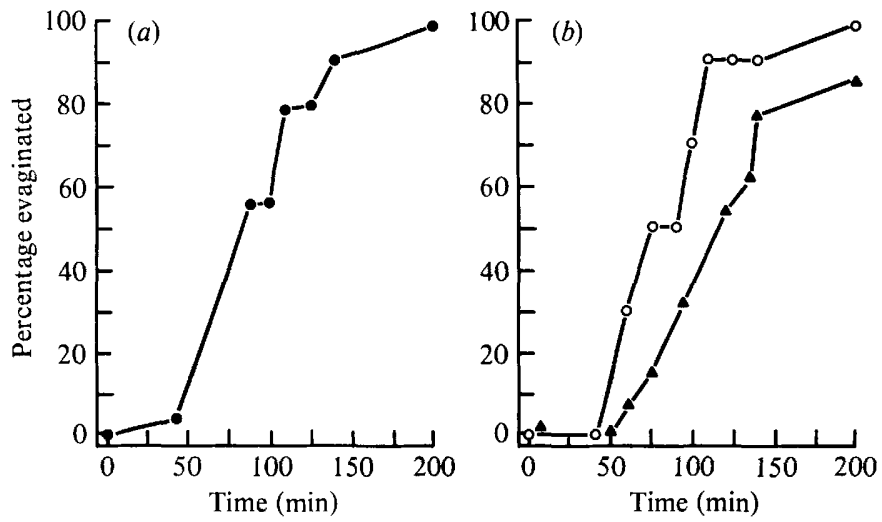

Fig. 7. Kinetics of evagination in exponential phase cultures starved for $20 \mathrm{~min}$ and then released into fresh medium at high temperature and high $\mathrm{pH}$, conditions conducive to mycelium formation. (a) evagination kinetics of unbudded cells; $(b)$ evagination kinetics of mother cells $(O)$ and buds $(\boldsymbol{A})$.

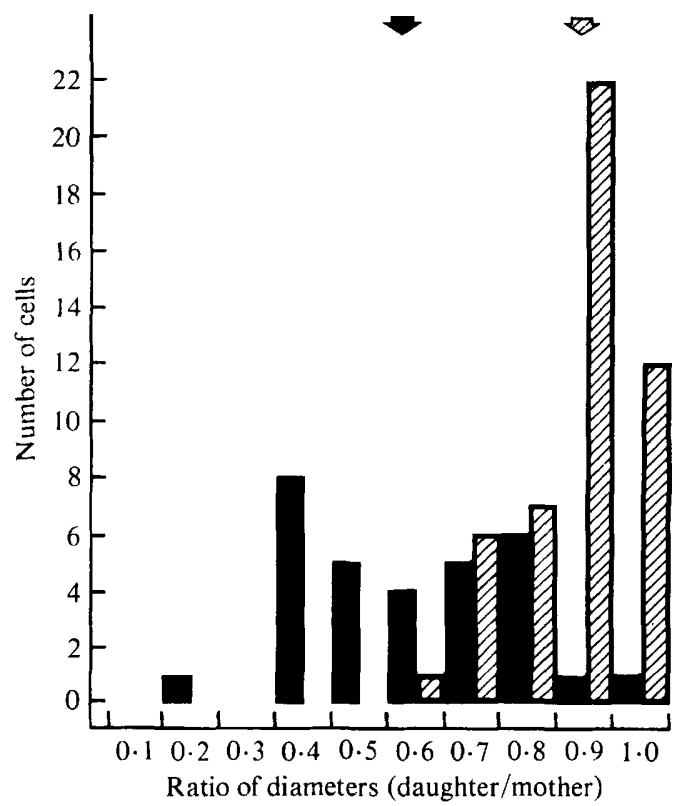

Fig. 8

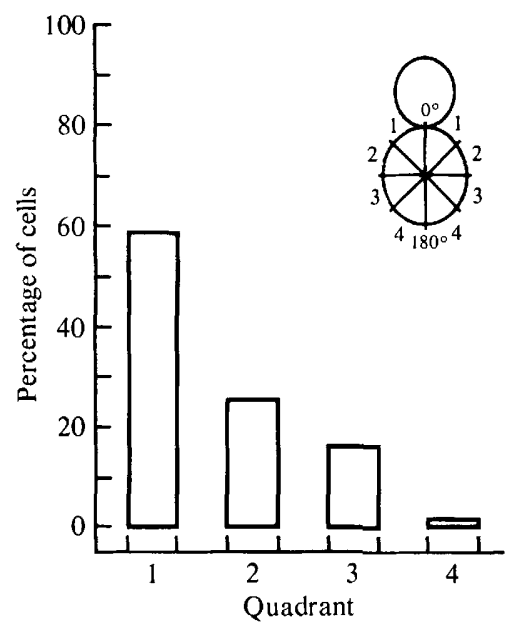

Fig. 9

Fig. 8. Relationship of daughter bud volume to the mode of mycelium formation in starved exponential phase cultures released into fresh medium at high temperature and high $\mathrm{pH}$, conditions conducive to mycelium formation. Solid bars, cells forming mycelia by apical elongation; hatched bars, cells forming mycelia by a sequence of evaginations. The arrows indicate the mean values for the respective classes. Cell diameters of mother cells and buds were measured directly on a video monitor (Fig. 1) and the cells were then followed for the mode of mycelium formation.

Fig. 9. The non-random position of mother cell evagination in starved exponential phase cells with large buds released into a perfusion chamber under conditions conducive to mycelium formation. The inset denotes the quadrants of the mother cell in relation to the original daughter bud. Quadrant 1 is adjacent to the original daughter bud in each case. One hundred cells were scored.

\section{Nuclear content and mycelium formation}

Since orientation of the spindle plaque body positioned on the nuclear membrane has been implicated in the position of evagination (Byers, 1981), it was of interest to test whether buds which formed evaginations and buds which resumed growth by apical elongation contained 
Table 3. Nuclear content of buds undergoing evagination or apical elongation after mycelial induction

$\begin{array}{lccr} & \begin{array}{c}\text { No. of cells } \\ \text { scored }\end{array} & \text { Mother cell } & \text { Bud } \\ \text { Apically elongating buds } & 204 & 100 & 83 \\ \text { Evagination on mother cell only } & 33 & 100 & 100 \\ \text { Evagination on bud and mother cell } & 59 & 100 & 100\end{array}$

nuclei. Experimental phase cells were therefore starved for $20 \mathrm{~min}$, then released into nutrient medium at $37^{\circ} \mathrm{C}, \mathrm{pH} 6.5$. Samples were then removed when apical elongation began, and when mother cell evagination and daughter cell evagination occurred. Samples were fixed, stained with acridine orange, and examined for nuclear content. The results are presented in Table 3 . In all cases in which an evagination was observed on a daughter bud, the bud contained a nucleus. However, $17 \%$ of those buds beginning apical elongation did not contain nuclei. Therefore, apical elongation did not require the presence of a nucleus in the bud.

\section{DISCUSSION}

Chaffin \& Sogin (1976) first presented evidence that budding cells actively growing in the exponential phase of a growth culture could not be induced to form mycelia by dilution into fresh medium at high temperature and $\mathrm{pH}$, conditions conducive to mycelium formation. They found that once cells had entered stationary phase, they were inducible. These results were subsequently confirmed, and it was also demonstrated that when cells entered stationary phase under zinc-limiting conditions, they accumulated as unbudded cells in phase G1 of the cell cycle (Soll \& Bedell, 1978). Together, these results suggested that cessation of growth in stationary phase, and in particular in phase Gl of the cell cycle, were prerequisites to the acquisition of pluripotency (the capacity, in this case, to resume growth in either the budding or the mycelial form). Recently, however, Mattia \& Cassone (1979) presented evidence that exponential phase cells could be induced to form mycelia under a particular set of conditions. These conflicting results would be reconcilable if a transient cessation of growth was all that was required for the acquisition of pluripotency. The results presented here show that a 10 to $20 \mathrm{~min}$ period of starvation is all that is necessary for pluripotency. Therefore, stationary phase per se is not a prerequisite. It is also demonstrated that cells at all points in the budding cycle acquired pluripotency. It is tempting to conclude that phase G1 is therefore not a prerequisite to pluripotency, but since the budding cycle can be dissociated to some degree from the nuclear cycle (Hartwell et al., 1974), we must await direct measurements of nuclear DNA content of starved exponential phase cells before conclusions can be drawn. At this point, we do not know why the transient cessation of cell growth leads to pluripotency.

Perhaps the most intriguing observation in this study is that starved budded cells progress through two very discrete modes of mycelium formation depending upon the size, and therefore the maturity, of the daughter bud. The apical resumption of growth in the mycelial form by immature buds indicates that the same cellular compartment can pass from one growth form to another. It is interesting to note that (1) in this transition, mycelial expansion always occurs in the region of the bud farthest from the mother cell; (2) subsequent evagination of the mother cell is suppressed; and (3) a nucleus in the bud is not essential. In contrast, more mature buds appear to have lost the capacity to expand apically. This is apparently not the result of nuclear content, since $80 \%$ of apically elongating buds also contain nuclei, but it may be related to the progress of septation, which must be more advanced in cells with larger buds. However, since the mechanisms which restrict bud size or which determine bud expansion versus apical mycelial elongation are not known (Farkas, 1979), it is probably premature to speculate on the molecular mechanisms which may be involved in the decision to form a mycelium in the alternative modes. 
The temporal sequence of evaginations in mother cells and daughter buds as well as the nonrandom position of mother cell evagination may both be related to the orientation and state of the spindle plaque body. Byers (1981) has suggested that the orientation of microtubules emanating from the spindle plaque body may dictate the site of evagination. It may very well be that the original spindle plaque is oriented towards the original bud and a duplicated plaque adjacent to the original plaque dictates the position of mother cell evagination. To test this possibility, a combined electron microscopic and immunofluorescent analysis of plaque and microtubule orientation is now in progress.

The authors wish to thank Mr L. Mitchell for help with the photography and Dr M. Solursh for the original idea of employing a Sykes-Moore perfusion chamber. This project was supported by grants AI 15743 from the National Institutes of Health and PCM82-02380 from the National Science Foundation.

\section{REFERENCES}

Bedell, G. \& Soll, D. R. (1979). The effects of low concentration of zinc on the growth and dimorphism of Candida albicans: evidence for zinc resistant and zinc sensitive pathways for mycelium formation. Infection and Immunity 36, 348-354.

Bedell, G., Werth, A. \& Soll, D. R. (1980). The regulation of nuclear migration and division during synchronous bud formation in released stationary phase cultures of the yeast Candida albicans. Experimental Cell Research 127, 103-113.

BRummel, M. \& Soll, D. R. (1982), The temporal regulation of protein synthesis during synchronous bud or mycelium formation in the dimorphic yeast Candida albicans. Developmental Biology 89, 211-224.

Buffo, J., Herman, M. A. \& Soll, D. R. (1983). A characterization of $\mathrm{pH}$ regulated dimorphism in Candida albicans. Mycopathologia (in the Press).

Byers, B. (1981). Cytology of the yeast life cycle. In The Molecular Biology of the Yeast Saccharomyces: Life Cycle and Inheritance, pp. 59-96. Edited by D. N. Strathern, E. W. Jones \& J. R. Broach. Cold Spring Harbor, N.Y.: Cold Spring Harbor Laboratory.

Chaffin, W. L. \& Sogin, S. L. (1976). Germ tube formation from zonal rotor fractions of Candida albicans. Journal of Bacteriology 126, 771-776.

FARKAS, V. (1979). Biosynthesis of cell walls of fungi. Microbiological Reviews 43, 117-144.

hartwell, L. H., Culotti, J., Pringle, J. R. \& Reid, B. J. (1974). Genetic control of the cell division cycle in yeast. Science $183,46-51$.

LeE, K. L., BuCKley, H. R. \& CAMpbell, H. R. (1975). An amino acid liquid synthetic medium for development of mycelial and yeast forms of Candida albicans. Sabouraudia 13, 148-153.
MATTIA, E. \& CASSONE, A. (1979). Inducibility of germtube formation in Candida albicans at different phases of yeast growth. Journal of General Microbiology 113, 439-442.

Mitchell, L. \& Soll, D. R. (1979a). Commitment to germ tube or bud formation during release from stationary phase in Candida albicans. Experimental Cell Research 120, 167-179.

Mitchell, L. \& Soll, D. R. (1979b). Septation during synchronous mycelium and bud formation in released stationary phase cultures of Candida albicans. Experimental Mycology 3, 298-309.

Soll, D. R. (1983). Candida albicans. In Fungal Dimorphism: with Emphasis on Fungi Pathogenic to Humans. Edited by P. J. Szaniszlo. New York: Plenum Publishing Corp. (in the Press).

SolL, D. R. \& BEDELL, G. (1978). Bud formation and the inducibility of pseudo-mycelium outgrowth during release from stationary phase in Candida albicans. Journal of General Microbiology 108, 173180.

Soll, D. R., Stasi, M. \& Bedell, G. (1978). The regulation of nuclear migration and division during pseudo-mycelium outgrowth in the dimorphic yeast Candida albicans. Experimental Cell Research 116, 207-215.

Soll, D. R., Bedell, G. W. \& Brummel, M. (1981 a). Zinc and the regulation of growth and phenotype in the infectious yeast Candida albicans. Infection and Immunity 32, 1139-1147.

Soll, D. R., Bedell, G., Thiel, J. \& Brummel, M. $(1981 b)$. The dependency of nuclear division on volume in the dimorphic yeast Candida albicans. Experimental Cell Research 133, 55-62. 